Effect of pre-treatment methods on the physicochemical and anti-nutritional properties of Bambara groundnut yoghurt

K.O. Salami*, O.R. Karim, M.A. Belewu and G.M. Olapade
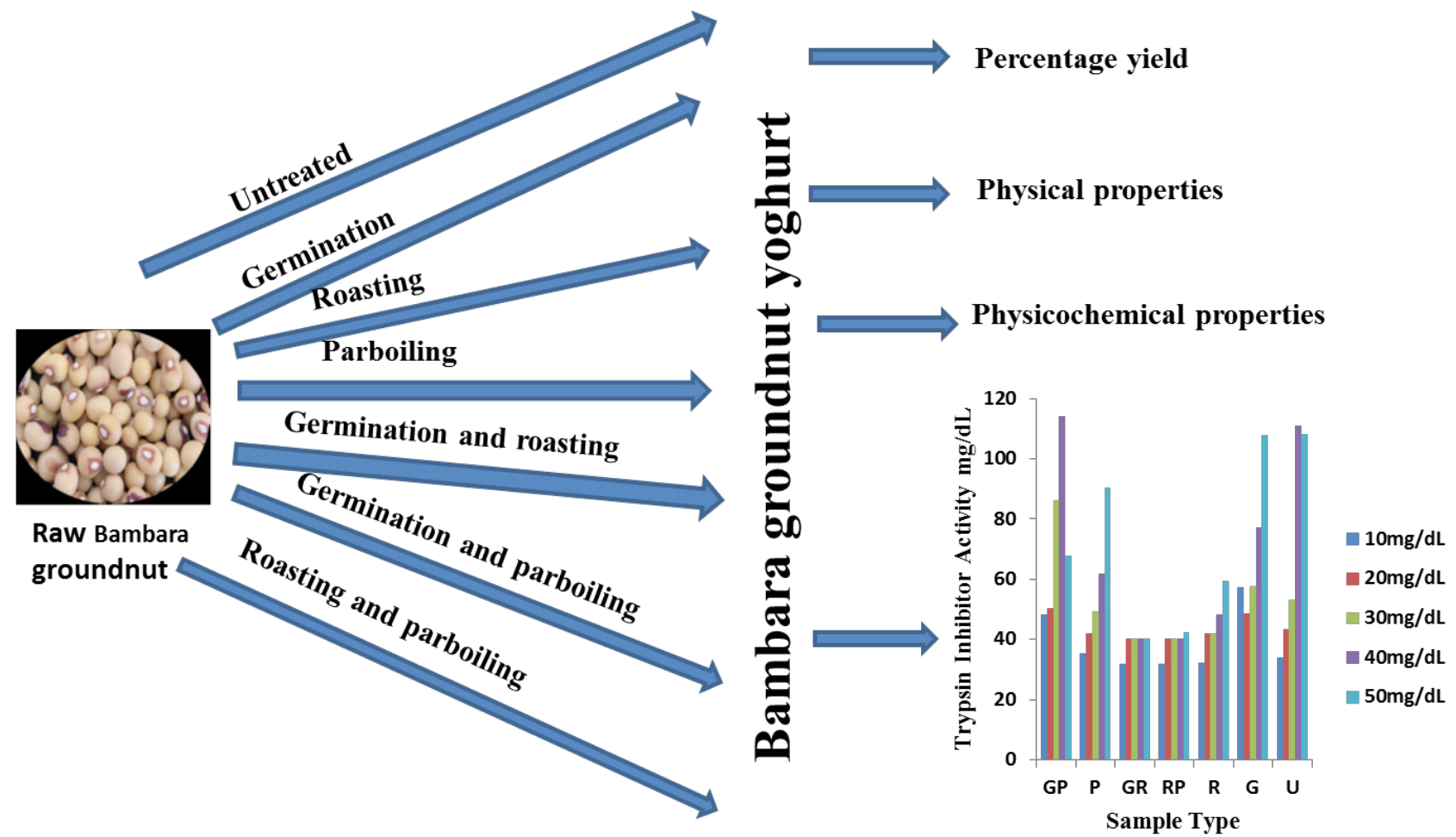

Anti nutritional factors

\title{
Highlights
}

- Germinated and roasted pre-treatment method produced the highest yield for both milk and yoghurt.

- Germination pre-treatment method improved the physicochemical properties of the yoghurt.

- Combined pre-treatment methods significantly reduced the anti-nutritional properties.

- Pre-treatments significantly improved the quality and stability of the yoghurt. 


\title{
RESEARCH ARTICLE
}

\section{Effect of pre-treatment methods on the physicochemical and anti-nutritional properties of Bambara groundnut yoghurt}

\author{
K.O. Salami ${ }^{1, *}$, O.R. Karim¹, M.A. Belewu² and G.M. Olapade ${ }^{1}$ \\ ${ }^{1}$ Department of Home Economics and Food Science, University of Ilorin, Ilorin. P.M.B. 1515, Ilorin, Nigeria. \\ ${ }^{2}$ Department of Animal Production, University of Ilorin, Ilorin. P.M.B. 1515, Ilorin, Nigeria.
}

Received: 07/04/2020; Accepted:31/10/2020

\begin{abstract}
Production of yoghurt from Bambara groundnut (BGN) had been reported to have some limitations on its stability and quality. This work was designed to determine the effect of pre-treatment methods on the physicochemical and antinutritional properties of Bambara groundnut yoghurt (BGNY). Seven yoghurt samples were made from BGN milk obtained from differently pre-treated BGN. The pre-treatment methods were germination $(\mathrm{G})$, roasting $(\mathrm{R})$, parboiling $(\mathrm{P})$, germination and roasting $(\mathrm{GR})$, roasting and parboiling $(\mathrm{RP})$, germination and parboiling (GP), while untreated (U) served as the control. The viscosity, specific gravity (SG), Brix, total dissolved solids (TDS) and least gelation concentration (LGC) of both the pre-treated and untreated BGNY were 11.30-19.40 mpals, 1.02-1.05 g/mL, 2.06.90 ( ${ }^{\circ}$ Brix), $2350-3470 \mathrm{ppm}$ and 6-12\% respectively. Significant differences $(\mathrm{P} \leq 0.05)$ were obtained for viscosity except for U-BGN and GP-BGN, and none recorded for specific gravity. No significant differences $(\mathrm{P} \leq 0.05)$ were recorded for sedimentation stability and also LGC except for GR-BGN and G-BGN. Yoghurt produced from G-BGN had the best values in LGC, Brix, TDS, SG and sedimentation stability. Pre-treatments significantly decreased anti-nutritional properties, while lowest values were recorded for GR (40.36 mg/dL) in trypsin inhibitor, RP (12.23 $\mathrm{mg} / \mathrm{kg})$ in tannin and GP $(4.64 \mathrm{mg} / \mathrm{mL})$ in phytate reductions. It could be concluded that BGNY can be produced from pre-treated BGN, as pre-treatment significantly improved the stability of the yoghurt and reduced the anti-nutritional properties; and can be recommended that combined pre-treatment with GR-BGN should be adopted for large scale production of yoghurt since it had the best qualities.
\end{abstract}

Keywords: Pre-treatment methods; Bambara groundnut yoghurt; physicochemical properties; anti-nutritional properties.

\section{INTRODUCTION}

Yoghurt is one of the oldest and most common fermented dairy products. It is a cultured 'food' obtained by controlled fermentation of milk by mixed culture of lactic acid bacteria selected to produce a characteristic mild clean lactic flavour and typical aroma (Falade et al., 2014; Adgidzi \& Abu, 2014). Conventionally, yoghurt is produced from cow's milk and a starter culture containing lactic acid bacteria such as; Lactobacillus bulgaricus and Streptococcus thermophilus (Farinde et al., 2008), but the scarcity of milk supply in developing countries, increasing population, high cost, availability and lactose intolerance has led to a continuous search for development of alternative milk from vegetable sources. In addition, in cases of vegetarian (those who do not take the flesh or products from an animal) nutrition, vegetable milk could be used. The alternative sources of milk reported for yoghurt production are; Bambara groundnuts (Majeste et al., 2017; Balogun et al., 2017; Falade et al., 2015), soybeans (Farinde et al., 2008), tiger nut (Adgidzi and Abu 2014; Charles et al., 2015), coconut (Belewu et al., 2013), groundnuts (Adeiye et al., 2013), sesame seeds (Quasem et al., 2009).

Bambara groundnut (BGN) (Voandzeia Subterranean L. Thouars) milk is an extract from dehulled seed. It can be used as a substitute for animal milk due to its high nutritive value and ability to ferment using starter cultures. BGN is a highly nutritious plant. The crop has been chosen for this research instead of other nuts because it is one of the under-utilized legumes in the country. Several farmers have renewed their interest for the cultivation of the crop in the arid savannah zones, due to its resistance to drought, pests and the ability to produce a reasonable crop when grown on poor soils (Massawe et al., 2002).

Several authors have reported on the nutritional composition of BGN seeds, particularly as a protein source (Belewu et al., 2008; Ijarotimi \& Esho, 2009; Oyeleke, 2012). They are believed to rank as the third grain legume after groundnuts and cowpea (Vigna unguiculata) (Amarteifio \& Moholo, 1998). The seed contains about 15-25\% protein, $4.5-7.4 \%$ fat, $3.2-4.4 \%$ ash, $49.0-63.5 \%$ carbohydrate, and 5.2- 6.4\% fiber (Ijarotimi \& Esho, 2009). Also, the report by Omoikhoje (2008) shows that the crop is a good source of fiber, calcium, iron, potassium and high in methionine, an essential sulfur-containing amino acid. The protein is of high quality, having a good balance of essential amino acids and relatively high lysine (6.8\%) and methionine (1.3\%) contents (Ellah \& Singh, 2008). The gross energy content has been reported to be higher than that of other more popular legumes such as cowpea, lentils and pigeon pea (Poulter, 1981).

Different authors have reported the effect of one of these methods like soaking to be effective in increasing milk yield 
due to softening of the plant material, opening of pores and also found some nutrients to increase since soaking acts on chemically bound compound, thereby making them readily available (Adekanmi et al., 2009: Frank et al., 2014). Also, Nnam (1997) reported that fermentation was also found to increase the proximate composition of the plant material fermented before milking except that vitamins are reduced because they are soluble in water. Fermentation also releases minerals from its organically bound complexes which increases its extraction rate into such food. Adeiye et al. (2013) stated that roasting was found to bring increase in ash, protein, crude fat and crude fibre, but there was a significant decrease in the moisture content of the nuts roasted before milking which is a good preservative attribute when shelf life is to be considered. Boiling and roasting were observed to increase or reduce the nutritional properties of milk yoghurt produced from plant materials. However, the findings from the various researchers gave one or two limitations on the quality and stability of the product using a single pre-treatment method. For instance, pre-treatment methods of soaking and parboiling had limitations of yield, separation (sedimentation) and beany flavour; fermentation and germination both improved the nutritional qualities but could not solve the issue of beany flavour which is one of the major factors of its acceptability.

Much attention has not been given to the effect of combined pre-treatment methods on the quality of BGN yoghurt. Hence, this study focused on four different pretreatments (soaking, roasting, germination, parboiling and their combination) for the production of Bambara yoghurt. The objectives were to determine the effect of pre-treatment methods on the physicochemical and anti-nutritional properties of Bambara groundnut yoghurt (BGNY).

\section{MATERIALS AND METHODS}

\section{Materials}

Matured and defect free cream / brown eye Bambara groundnut variety and starter culture were obtained from Oja tuntun food market, Ilorin, Kwara State, Nigeria. Other materials and reagents used for all analysis were obtained from the Food processing laboratory in the Department of Home Economics and Food Science, University of Ilorin and were all of analytical grade.

\section{Method of analysis}

Seven yoghurt blends were produced from Bambara groundnut milk (BGNM) obtained after different pretreatment methods of BGN. The pre-treatment methods were germination, roasting, parboiling, germination and roasting, roasting and parboiling, and germination and parboiling, while the untreated served as the control.

A modified method of Okafor et al. (2014) was adopted for the germination of BGN for milk production. After soaking, seeds were spread on jute bags which were moistened every $12 \mathrm{~h}$ to germinate for $72 \mathrm{~h}$. The vegetative parts (hulls and radicle) of the germinated BGN seeds were removed by rubbing between palms. The BGN seeds were then wet-cleaned and dried for $6 \mathrm{~h}$ using a cabinet drier (fabricated model by NCAM). Two hundred (200 g) of dried BGN seeds were soaked in $2 \mathrm{~L}$ of clean water for $2 \mathrm{~h}$ to soften the cotyledons after which they were wet-milled in an attrition mill (Model SK-24-MS), filtered to obtain the milk which was boiled with other ingredients for 15 min. The final milk obtained was filtered again to remove scum, cooled, packaged in polyethylene terephthalate (PET) bottles and kept in the refrigerator at $4{ }^{\circ} \mathrm{C}$ for further analyses.

The method of Ndidi et al. (2014) was modified and adopted for roasting of the BGN seeds. The seeds after soaking were dehulled, rinsed with water and dried for $6 \mathrm{~h}$ using a cabinet drier. They were then roasted using frying pan (open roasting method) at about $300{ }^{\circ} \mathrm{C}$ for $15 \mathrm{~min}$. The milk was obtained from the roasted nuts as previously described.

Parboiled Bambara groundnut milk was produced using a modified method of Balogun et al. (2017). After soaking, the seeds were dehulled and rinsed with water. They were then parboiled in boiling water for $30 \mathrm{~min}$, rinsed, wetmilled and sieved. The milk was obtained following the same process described above.

A combination of these treatments (germination and roasting, germination and parboiling as well as roasting and parboiling) was carried out following the previous procedures.

The method described by Yusuf (2017) was adopted with slight modification for the production of yoghurt from the BGNM samples. The differently pre-treated BGNM samples were pasteurized at $85{ }^{\circ} \mathrm{C}$ for $30 \mathrm{~min}$ and cooled down to $40-45^{\circ} \mathrm{C}$. BGNM were homogenized using blender (Model PT10-35GT-D). One litre (1 L) of homogenized BGNM were inoculated with $5 \mathrm{~g}$ of commercial starter (pure culture of mixed strains of Lactobacillus bulgaricus and Streptococcus thermophillus) and incubated at $38^{\circ} \mathrm{C}$ for $10 \mathrm{~h}$. The yoghurt was filled into sterile plastic bottles, corked and stored in refrigerator at 4 ${ }^{\circ} \mathrm{C}$ for subsequent analysis.

\section{Physicochemical properties determination}

The milk and yoghurt yield were determined according to the method described by Falade et al. (2015). The Viscosity of the samples was determined using the method described by Onwuka (2005) method. Sedimentation stability of the BGNY was determined using the method described by Quasem et al. (2009). Least Gelation Concentration (LGC) was determined by the method of Sathe and Salunkhe (1981). The Total dissolved solid of the BGNY was determined using the microwave technique described by Reh and Gerber (2003). Specific gravity was determined using AOAC, (2002) method. Brix was determined using AOAC (2010) method.

\section{Determination of anti-nutritional components}

Trypsin activity of yoghurt samples was determined using the method described by Jayaraman (1981). Tannin content was determined using the Folin-Denis colorimetric method as described by Kirk and Sawyer (1998). Phytate content was determined according to the method described by Wheeler and Ferrel (1971). 


\section{Statistical analysis}

All the experiments were carried out in triplicates and analysis of Variance (ANOVA) was performed. The mean scores were computed and a significant difference among the mean was determined at 5\% level using SPSS 20.00 version.

\section{RESULTS AND DISCUSSIONS}

\section{Yield of milk and yoghurt from pre-treated Bambara groundnut}

The percentages of milk and yoghurt yield are presented in Table 1. Milk yield ranged from 48 to $59 \%$ pre-treatment methods. From GR BGN had the highest yield in milk (59\%) productions followed by RP-BGNY with 58\% value, while U-BGNY recorded the least value of $48 \%$. The high value obtained in GR-BGNY and RP-BGNY may be due to the combination of pre-treatments (germination, roasting and parboiling) employed during processing of the samples which is in agreement with the report of Victor et al. (2016) that high temperature increases milk yield due to the diffusion of milk solids. U-BGNY recorded the least value because it is un-treated. The milk yield (48 to
$59 \%$ ) obtained in this study is higher than $47 \%$ obtained by Falade et al. (2014) for Bambara milk. Bambara groundnut yoghurt yield ranged from 91 to $97 \%$. GR-BGNY recorded the highest yoghurt yield of $97 \%$ followed by RP-BGNY sample with $96 \%$, while GP-BGNY recorded the least yoghurt yield of $91 \%$. The high yoghurt yield of the RPBGN sample may be due to the formation of protein gels and curd during heating and other chemical treatments (Abdel-Rahman et al., 2011).

\section{Viscosity of yoghurt from pre-treated Bambara groundnut}

The viscosity of the BGNY samples as shown in Figure 1 ranged from 11.30 to 19.40 mpals. The yoghurt from U-BGN had the highest value (19.40 mpals), while R-BGN samples recorded the least value (11.30 mpals). Moreover the results showed significant differences $(\mathrm{p} \leq 0.05)$ among the samples except for GP-BGN and U- BGN samples. Viscosity is affected by the strength and number of bonds between casein micelles in yoghurt, as well as their structure and spatial distribution (Izadi et al., 2014). The low value of other samples compared to U- BGN yoghurt might be because; yoghurt is a gel or matrix of casein micelles with entrapped water. Hence, heat and other treatment

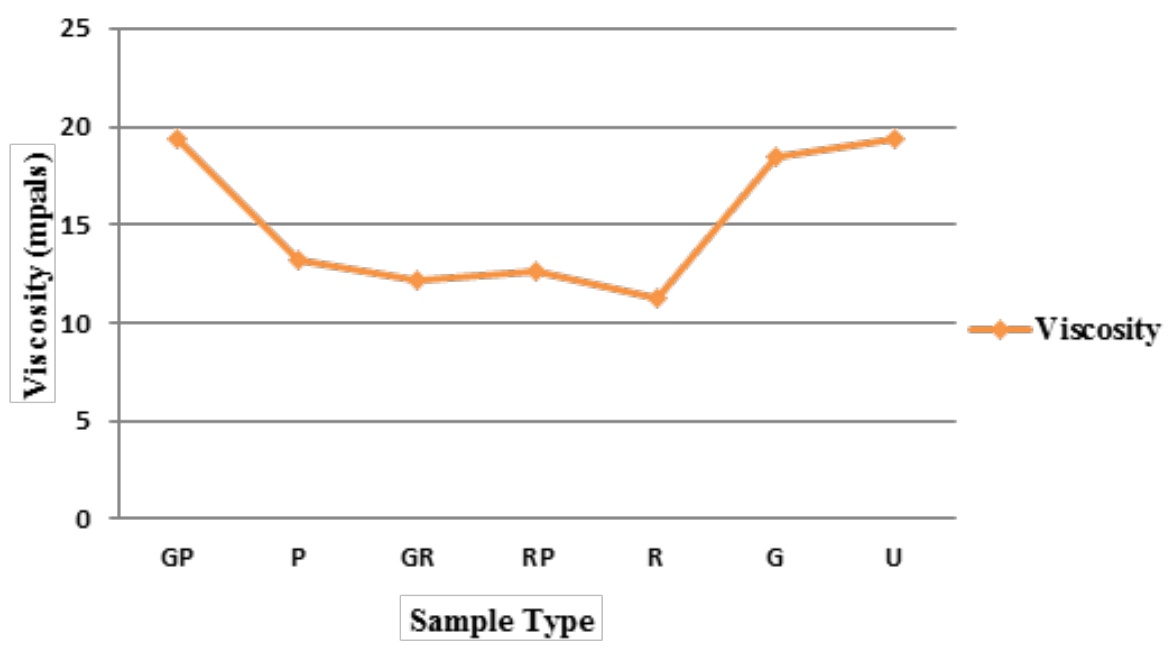

Figure 1: Viscosity of yoghurt from pre-treated Bambara groundnut.

Keys: $\mathrm{GP}=$ Germinated parboiled $\quad \mathrm{P}=$ Parboiled $\quad \mathrm{GR}=$ Germinated roasted $\quad \mathrm{R}=$ Roasted $\quad \mathrm{RP}=\mathrm{Roasted}$ parboiled $\mathrm{G}=$ Germinated $\quad \mathrm{U}=$ Untreated

Table 1: Yield of milk and yoghurt from pre-treatment Bambara groundnut.

\begin{tabular}{|c|c|c|}
\hline & Samples Milk Yield (\%) & Yoghurt Yield (\%) \\
\hline GP & 49 & 91 \\
\hline $\mathbf{P}$ & 51 & 93 \\
\hline GR & 59 & 97 \\
\hline RP & 58 & 96 \\
\hline $\mathbf{R}$ & 50 & 95 \\
\hline G & 53 & 94 \\
\hline $\mathbf{U}$ & 48 & 92 \\
\hline
\end{tabular}

Keys: GP= Germinated parboiled $\mathrm{P}=$ Parboiled $\quad \mathrm{GR}=$ Germinated roasted $\quad \mathrm{R}=$ Roasted 
employed for other samples may have interrupted the gel structure of the sample and rearrangement of protein and protein-protein contacts (Izadi et al., 2014). Also, increased acidity causes proteins to denature and form gel resulting to the characteristic viscous nature of yoghurts. According to Adgidzi et al. (2015) pasteurization is believed to modify milk protein so as to enhance proper viscosity and gelatinization of yoghurt, thus account for the uniformity and smoothness in the body texture of the product. Muhammad et al. (2008) reported that yoghurts with low protein contents tend to have low viscosity due to low water-holding capacity of coagulum.

\section{Specific gravity, Brix and total dissolved solid of yoghurt from pre-treated Bambara groundnut}

The results of the specific gravity are presented in Table 2 . The analysis of variance shows that the mean values for specific gravity were not significantly different $(\mathrm{P}>0.05)$. The mean values of BGNY ranged from 1.02 to $1.05 \mathrm{~g} /$ $\mathrm{mL}$. Samples produced from R- BGN the highest value of (1.05 g/mL) while GP-BGN and G-BGN samples show the least $(1.02 \mathrm{~g} / \mathrm{mL})$. The low value obtained by these samples is a result of the addition of water for germination and parboiling. The addition of water causes the decrease in specific gravity of milk or yoghurt as the specific gravity of yoghurt is slightly higher than water. Thus the change in composition changes the specific gravity of yoghurt. While the high score recorded by R- BGN and RP-BGN sample may be due to the removal of fat during dry heating, which increases the specific gravity because the weight of fat is much lower than the water. The results obtained in this study were in line with the findings of Grimaud et al. (2004) and similar trends were found in the findings of Khan et al. (2008).

The Brix content of BGNY ranged from 2.0 to 6.90 ( ${ }^{0}$ Brix). G-BGN had the highest value of 6.90 followed by U-BGN sample. RP-BGN sample recorded the least score. This shows that the heat employed during processing has reduced the sugar in the sample. Brix is a measure of dissolved solids in sugar solutions including fruit juices. It is based upon the specific gravity of sucrose in water solutions. The Brix scale ( ${ }^{\circ}$ Brix) is based on density tables developed in the 1800 's by Adolf Brix. These tables have been modelled mathematically as polynomial formulas.

The total dissolved solids (TDS) of BGNY ranged from 2350 to $3470 \mathrm{ppm}$. G-BGN sample had the highest value (3470 ppm). This can be mainly attributed to the contribution of substance formed during germination while the roasted parboiled sample had the least (2350 ppm). The total solids are an indication of the dry matter content in the yoghurt samples (Belewu et al., 2010; Khalifa et al., 2011).

\section{Least gelation capacity and sedimentation stability of yoghurt from pre-treated Bambara groundnut}

The least gelation concentration (LGC) which is defined as the lowest protein concentration at which the gel remained in the inverted tube was used as an index of gelation capacity. The lower the LGC shows the better the gelating ability of the protein ingredient (Akintayo et al., 1999). The least gelation capacity of BGNY ranged from 6 to $12 \%$ (Table 3). GR- BGN sample had the highest value (12\%) while ordinary G-BGN sample had the least value $(6 \%)$. The high gelation capacity of GR-BGN sample might be due to formation of protein gels when subjected to heat, salts, acids, alkalis and other chemical treatments (AbdelRahman et al., 2011). Heating and cooling of proteinwater systems are one of the most common means of gel formations in food processing (Abdel-Rahman et al., 2011) while the LGC of germinated G-BGN samples indicates the gelation capacity and the lower the LGC, the better the gelling ability of proteins. Gelling ability is a function of the ability of the samples to absorb water and swell. The low gelation concentration observed may be an asset in the use of these pre-treatments for the formation of curd or as an additive to other gel forming materials in food products (Aremu et al., 2007).

Sedimentation stability is the measure of the stability of the milk or yoghurt under chilling storage. It helps in the determination of stability index in terms of separation of vegetable milk to the lower layer (condensed sediment phase) and the top layer (clear serum phase) thus is expressed as a ratio of the sediment height to the total height. The range of sedimentation stability ranged from 0.74 to 0.86 (Table 3 ). There was no significant difference $(\mathrm{p}<0.05)$ among the samples analyzed. P-BGN had the highest value (0.86) while RP- BGN had the least value

Table 2: Specific gravity, Brix and total dissolved solids of yoghurt from pre-treated Bambara groundnut.

\begin{tabular}{lccc}
\hline Sample & Specific gravity & ${ }^{\circ}$ Brix & Total dissolved solid (ppm) \\
\hline $\mathbf{G}$ & $1.02^{\mathrm{a}} \pm 0.00$ & $6.90^{\mathrm{a}} \pm 0.14$ & $3470^{\mathrm{a}} \pm 0.00$ \\
\hline $\mathbf{R}$ & $1.06^{\mathrm{a}} \pm 0.00$ & $2.20^{\mathrm{d}} \pm 0.00$ & $2691^{\mathrm{e}} \pm 1.41$ \\
\hline $\mathbf{G R}$ & $1.03^{\mathrm{a}} \pm 0.00$ & $2.20^{\mathrm{d}} \pm 0.00$ & $3243^{\mathrm{b}} \pm 9.89$ \\
\hline $\mathbf{R P}$ & $1.05^{\mathrm{a}} \pm 0.00$ & $2.00^{\mathrm{d}} \pm 0.00$ & $2350^{\mathrm{a}} \pm 14.14$ \\
\hline $\mathbf{G P}$ & $1.02^{\mathrm{a}} \pm 0.00$ & $2.00^{\mathrm{d}} \pm 0.00$ & $3000^{\mathrm{d}} \pm 14.14$ \\
\hline $\mathbf{P}$ & $1.03^{\mathrm{a}} \pm 0.00$ & $3.30^{\mathrm{c}} \pm 0.14$ & $2345^{\mathrm{f}} \pm 7.07$ \\
\hline $\mathbf{U}$ & $1.03^{\mathrm{a}} \pm 0.00$ & $4.45^{\mathrm{b}} \pm 0.71$ & $3040^{\mathrm{c}} \pm 14.14$ \\
\hline
\end{tabular}

Values with the same superscripts along the column were not significantly different $(\mathrm{p}<0.05)$

Keys: $\mathrm{GP}=$ Germinated parboiled $\mathrm{P}=$ Parboiled $\quad \mathrm{GR}=$ Germinated roasted $\mathrm{R}=$ Roasted $\mathrm{RP}=$ Roasted parboiled $\quad \mathrm{G}=$ Germinated $\mathrm{U}=$ Untreated 
Table 3: Least gelation concentration and sedimentation stability of yoghurt from pre-treated Bambara groundnut.

\begin{tabular}{lcc}
\hline Sample & Least gelation Concentration (at 20 $\left.{ }^{\circ} \mathbf{C}\right)$ & Sedimentation stability \\
\hline $\mathbf{G P}$ & $8.00^{\mathrm{bc}} \pm 0.00$ & $0.84^{\mathrm{a}} \pm 0.12$ \\
\hline $\mathbf{P}$ & $10.00^{\mathrm{b}} \pm 0.00$ & $0.86^{\mathrm{a}} \pm 0.00$ \\
\hline $\mathbf{G R}$ & $12.00^{\mathrm{a}} \pm 0.00$ & $0.84^{\mathrm{a}} \pm 0.13$ \\
\hline $\mathbf{R P}$ & $8.02^{\mathrm{bc}} \pm 0.00$ & $0.74^{\mathrm{b}} \pm 0.00$ \\
\hline $\mathbf{R}$ & $10.00^{\mathrm{b}} \pm 0.00$ & $0.83^{\mathrm{a}} \pm 0.00$ \\
\hline $\mathbf{G}$ & $6.03^{\mathrm{d}} \pm 0.00$ & $0.78^{\mathrm{b}} \pm 0.14$ \\
\hline $\mathbf{U}$ & $10.03^{\mathrm{b}} \pm 0.00$ & $0.80^{\mathrm{a}} \pm 0.00$ \\
\hline
\end{tabular}

Values with the same superscripts along the column were not significantly different $(p<0.05)$ parboiled $\mathrm{P}=$ Parboiled $\quad \mathrm{GR}=$ Germinated roasted $\quad \mathrm{R}=$ Roasted $\quad \mathrm{RP}=$ Roasted parboiled Keys: GP $=$ Germinated $\mathrm{U}=$ Untreated

(0.74). However, the values obtained were higher than the range of $0.16-0.51$ obtained by Murevanhema and Jideani, (2014).

\section{Colour profile of yoghurt from pre-treated Bambara groundnut}

The results of colour profile $\left(\mathrm{L}^{*}, \mathrm{a}^{*}, \mathrm{~b}^{*}\right)$ are presented in Table 4 . The samples varied significantly $(\mathrm{P} \leq 0.05)$ from one another in all the colour parameters evaluated. The colour parameter was measured using Minolta portable chroma-meter.

The lightness result shows that U-BGN sample had the highest value (75.61) while sample produced from RP-BGN recorded the lowest value (63.82). High values obtained for these samples in $\mathrm{L}^{*}$ could be due to the leaching of colour pigments of Bambara nut during soaking, germination and parboiling operation thus, making them whither (Ojinnaka et al., 2013) while the low value obtained by roasted parboiled (RP) might be due to dry and moist heat (roasting and parboiling) undergone that has darkened or decreased the lightness of the Bambara nut during processing.

The Redness $\left(\mathrm{a}^{*}\right)$ of the BGNY samples ranges from 8.80 to 10.00 . G-BGN recorded the highest value (10.00) while GP-BGN and R-BGN samples had the lowest value (8.80). There was a significant difference among the samples. The high redness value obtained by G-BGN yoghurt sample might be due to compound formation encountered in germinated products which might have add to the redness.

The yellowness $\left(b^{*}\right)$ of the samples also ranges from 11.12 to 13.77 . GR-BGN yoghurt sample had the highest value (13.77) followed by the G-BGN sample with the value (13.68). The high value obtained in the sample produced from GR-BGN might be due to the fact that germination increases both respiration and metabolic activity that allows the mobilization of primary and secondary metabolites (Bohoua et al., 2007) and it might also be as a result of roasting which might have imparted brown colour to the nut.

\section{Trypsin inhibition activity, tannin and phytate content of yoghurt from pre-treated Bambara groundnut}

Trypsin inhibition activity was determined at $10 \mathrm{mg} / \mathrm{dL}$, $20 \mathrm{mg} / \mathrm{dL}, 30 \mathrm{mg} / \mathrm{dL}, 40 \mathrm{mg} / \mathrm{dL}$ and $50 \mathrm{mg} / \mathrm{dL}$. The effect of pre-treatments on trypsin inhibitor activity is shown in Figure 2.

Trypsin inhibitions range from 31.93 to $57.34 \mathrm{mg} / \mathrm{dL}$, 40.31 to $50.39 \mathrm{mg} / \mathrm{dL}, 40.36$ to $57.57 \mathrm{mg} / \mathrm{dL}, 40.36$ to 114 $\mathrm{mg} / \mathrm{dL}$ and 42.49 to $108.29 \mathrm{mg} / \mathrm{dL}$ in $10 \mathrm{~mL}, 20 \mathrm{~mL}, 30$ $\mathrm{mL}, 40 \mathrm{~mL}$ and $50 \mathrm{~mL}$ respectively of yoghurt samples, There were significant $(\mathrm{P} \leq 0.05)$ differences among all the samples and volume assessed. It was noticed that in almost all the volume analyzed trypsin inhibitor content of GRBGN and RP-BGN samples had the lowest value. Hence, pre-treatments such as germination and combination of roasting and parboiling are known to contribute to the reduction of anti-nutritional factors in the sample (SunnyRoberts, 2004). Trypsin inhibition contents in untreated samples recorded the highest value in all the volume assessed. According to Venter and Van Eyssen (2001) are compounds that interfere with protein digestion, they cause pancreatic enlargement and enhance chemically induced pancreatic tumors. However, the trypsin inhibitors are heatlabile in nature and this suggests that they can be inactivated by cooking (Prathibha et al., 1995). This revealed why a low value was observed for RP-BGN samples. It has also been reported that in well cooked foods, the trypsin inhibitors may not interfere with digestion (Adane et al. 2013).

The effect of pre-treatment on the tannin content of BGNY is shown in Figure 3. The tannin contents of the products were significantly different $(p<0.05)$ ranging from 12.23 to $80.39 \mathrm{~kg}$. U-BGN sample recorded the highest value $(80.39 \mathrm{mg} / \mathrm{kg})$ while the RP-BGN sample had the least value $(12.23 \mathrm{mg} / \mathrm{kg})$. Lower values $(0.035$ to 0.130 $\mathrm{mg} / 100 \mathrm{~g})$ were recorded for breakfast cereals made from Pigeon pea and Sorghum by (Mbaeyi. 2005). The variation in value can be as a result of the different crops used. While the lower value realized the pre-treated samples in this study is as a result of the activity of heat employed and probably leaching in water which gave RP-BGN its lowest value when compared to other samples. Tannins 
Table 4: Colour profile of yoghurt from pre-treated Bambara groundnut.

\begin{tabular}{lccc}
\hline Sample & $\mathbf{L}^{*}$ & $\mathbf{a}^{*}$ & $\mathbf{b}^{*}$ \\
\hline $\mathbf{G P}$ & $71.32^{\mathrm{b}} \pm 2.19$ & $8.80^{\mathrm{d}} \pm 0.11$ & $12.49^{\mathrm{b}} \pm 0.80$ \\
\hline $\mathbf{P}$ & $74.88^{\mathrm{a}} \pm 2.25$ & $8.90^{\mathrm{d}} \pm 0.19$ & $11.64^{\mathrm{bc}} \pm 0.80$ \\
\hline $\mathbf{G R}$ & $65.36^{\mathrm{c}} \pm 1.42$ & $9.70^{\mathrm{ab}} \pm 0.30$ & $13.77^{\mathrm{a}} \pm 0.85$ \\
\hline $\mathbf{R P}$ & $63.82^{\mathrm{c}} \pm 0.01$ & $9.09^{\mathrm{cd}} \pm 0.24$ & $11.22^{\mathrm{c}} \pm 0.51$ \\
\hline $\mathbf{R}$ & $70.96^{\mathrm{b}} \pm 2.63$ & $8.80^{\mathrm{d}} \pm 0.39$ & $11.12^{\mathrm{c}} \pm 1.24$ \\
\hline $\mathbf{G}$ & $74.51^{\mathrm{a}} \pm 1.07$ & $10.00^{\mathrm{a}} \pm 0.13$ & $13.68^{\mathrm{a}} \pm 0.32$ \\
\hline $\mathbf{U}$ & $75.61^{\mathrm{a}} \pm 0.01$ & $9.38^{\mathrm{bc}} \pm 0.68$ & $12.76^{\mathrm{ab}} \pm 0.17$ \\
\hline
\end{tabular}

Values with the same superscripts along the column were not significantly different $(\mathrm{p}<0.05)$
Keys: $\mathrm{GP}=$ Germinated parboiled
$\mathrm{P}=$ Parboiled
$\mathrm{GR}=$ Germinated roasted
$\mathrm{R}=$ Roasted
$\mathrm{RP}=$ Roasted parboiled

$\mathrm{G}=$ Germinated $\quad \mathrm{U}=$ Untreated

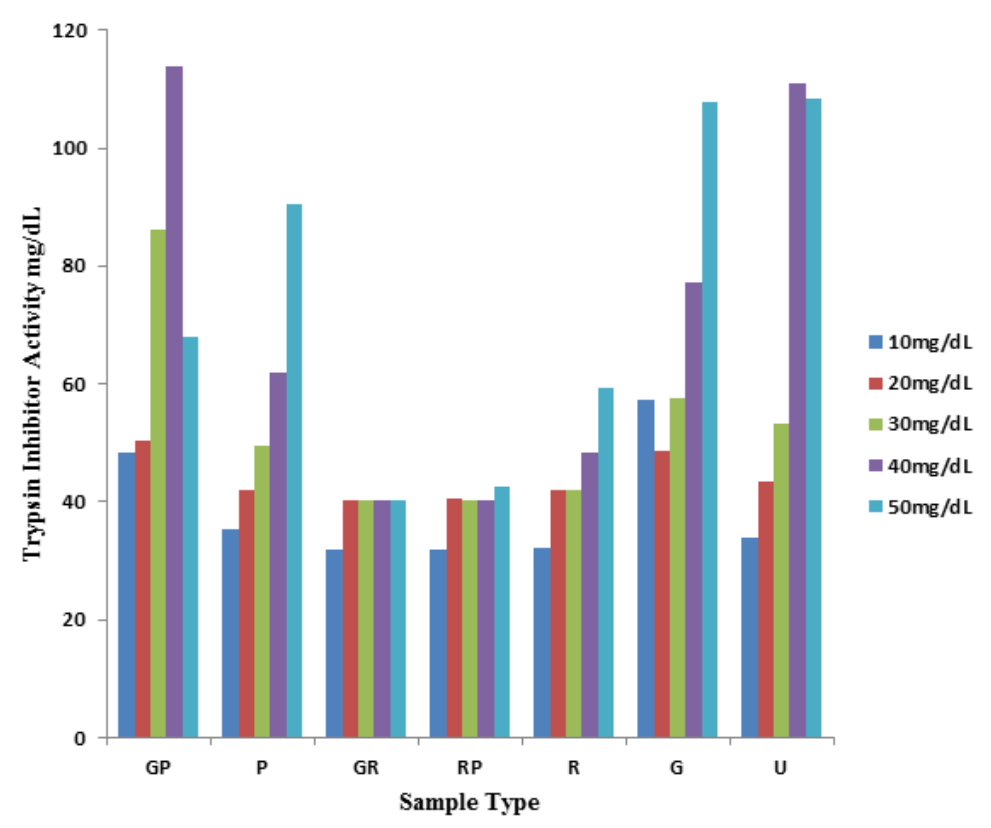

Figure 2: Trypsin inhibitor activity of yoghurt from pre-treated Bambara groundnut.

Keys: $\mathrm{GP}=$ Germinated parboiled $\quad \mathrm{P}=$ Parboiled $\quad \mathrm{GR}=$ Germinated roasted

$\mathrm{G}=$ Germinated $\quad \mathrm{U}=$ Untreated

$\mathrm{GR}=$ Germinated roasted $\quad \mathrm{R}=$ Roasted

$\mathrm{RP}=$ Roasted parboiled

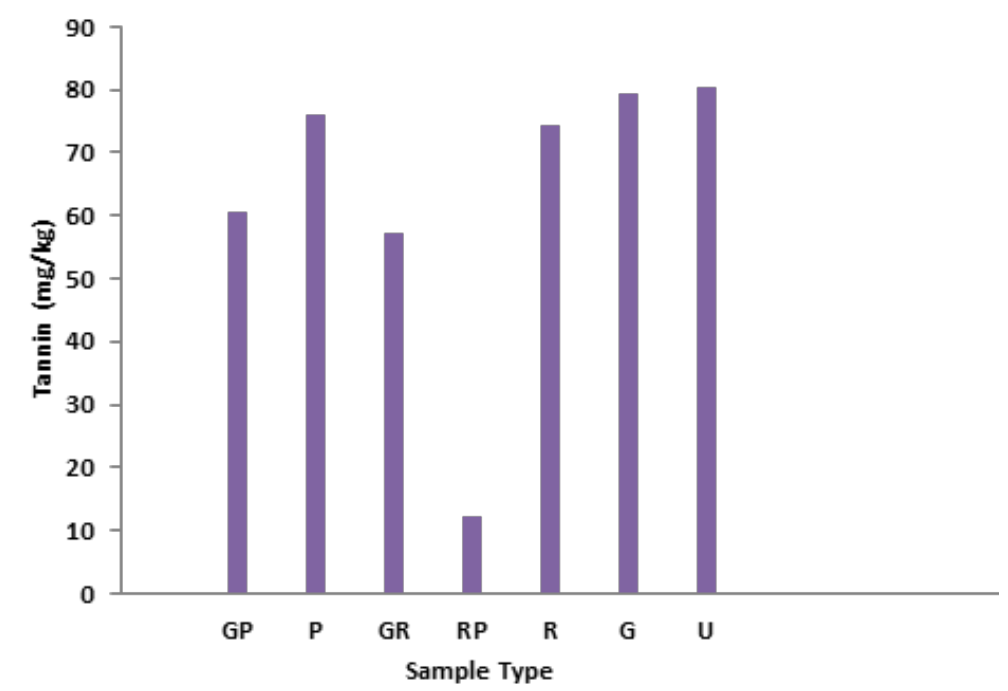

Figure 3: Tannin content of yoghurt from pre-treated Bambara groundnut.

Keys: $\mathrm{GP}=$ Germinated parboiled

$\mathrm{P}=$ Parboiled

$\mathrm{GR}=$ Germinated roasted

$\mathrm{R}=$ Roasted

$\mathrm{RP}=$ Roasted parboiled 


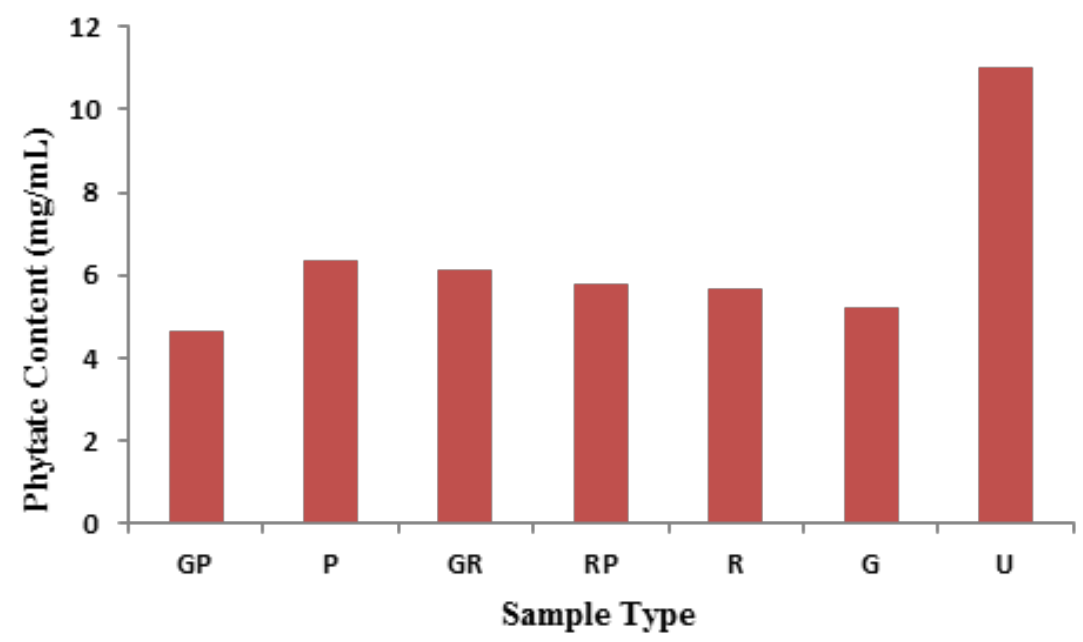

Figure 4: Phytate content of yoghurt from pre-treated Bambara groundnut.

Keys: $\mathrm{GP}=$ Germinated parboiled $\quad \mathrm{P}=$ Parboiled $\quad \mathrm{GR}=$ Germinated roasted $\quad \mathrm{R}=$ Roasted $\quad \mathrm{RP}=\mathrm{Roasted}$ parboiled $\mathrm{G}=$ Germinated $\quad \mathrm{U}=$ Untreated

are located in the seed coat of the grains and are known to have deleterious effects due to their strong interactions with proteins, with the resulting complexes which are not readily digested by monogastrics. This lowers the protein digestibility and weight (Mbaeyi. 2005; El-Niely, 2007). Hence, it is then evident from this study that combination of treatment methods can reduce the tannin content in legume to its barest minimum level.

The result of BGNY phytate content is presented in Figure 4. There were significant differences $(\mathrm{P}<0.05)$ among the samples. Phytate content of BGNY samples ranged between 4.64 to $11.02 \mathrm{mg} / \mathrm{mL}$. The sample produced from U-BGN BGN recorded the highest value $(11.02 \mathrm{mg}$ / $\mathrm{mL}$ ) while GP-BGN sample gave the least value (4.64 $\mathrm{mg} / \mathrm{mL}$ ) followed by the GR-BGN sample which had the value $(5.22 \mathrm{mg} / \mathrm{mL})$. This implies that the combination of germination and parboiling or roasting is efficient to reduce the phytate content of BGNY. Also reduction in these antinutrients may be associated with several factors such as germination and water leaching in water used for parboiling during the production of milk used for the BGNY. This agrees with the report of Agarwal and Verma (2011) that soaking or parboiling for several hours causes 60 to $90 \%$ reduction in phytate content. Phytate has been reported to bring about a reduction in bioavailability and chelating of the divalent minerals such as calcium, iron and magnesium (Yusuf et al. 2007).

\section{CONCLUSION}

GR pre-treatment method (GR-BGN) had the highest yield for both milk and yoghurt production; G-BGNY had the best values in least gelation concentration, brix, total dissolved solid, specific gravity and sedimentation stability. Pre-treatments significantly reduced the antinutritional properties; lowest values were recorded for GR-BGNY in (trypsin inhibitor), RP-BGNY (tannin) and GP-BGNY (phytate), while U-BGNY recorded the highest values respectively. It could be concluded that BGNY can be produced from pre-treated BGN, as pre-treatment significantly improved the stability of the yoghurt and reduced the anti-nutritional properties; and can be recommended that combined pre-treatment with GR-BGN should be adopted for large scale production of yoghurt since it had the best qualities.

\section{ACKNOWLEDGEMENT}

The authors acknowledged the Department of Home Economics and Food Science, Faculty of Agriculture, University of Ilorin, Ilorin, Nigeria for using the food processing laboratory for the production of the yoghurt samples and carrying out the analysis.

\section{STATEMENT OF CONFLICTS OF INTEREST}

The authors declare that there is no conflict of interest.

\section{REFERENCES}

Abdel-Rahman, S.M., Eltayeb, Ali O. Ali, Azza A. AbouArab and Ferial, M.A. (2011). Chemical composition and functional properties of flour and protein isolate extracted from Bambara groundnut (Vigna subterranean). African Journal of Food Science, 5(2): 82-90.

Adane, T., Shimelis, A., Negussie, R., Tilahun, B. and Haki, G.D. (2013). Effect of processing method on the proximate composition, mineral content and antinutritional factors of Taro (Colocasia esculenta, L.) growth in Ethiopia. African Journal of Food, Agriculture, Nutrition and Development, 13(2): 118128.

Adeiye, O.A., Gbadamosi, S.O. and Taiwo, A.K. (2013). Effects of some processing factors on the characteristics of stored groundnut milk extract Academic Journals of Food Science, 7(6): 134-142. 10.5897/AJFS12.149.

Adekanmi, O.K., Oluwatooyin, O.F. and Yemisi, A. A. (2009). Influence of processing techniques on the nutrients and anti-nutrients of tigernut (Cyperus esculentus L.).World Journal of Dairy \& Food Science, 4: 88-93.

Adgidzi, E.A. and Abu, J.O. (2014). Effects of processing 
methods on the quality of yoghurt- like products from tigernut (Cyperus Esculentus). Production Agriculture and Technology Journal, 10(2): 145-156.

Agarwal, S. and Verma, J. (2011). Haemogram profile of dengue fever in adults during 19 September - 12 November 2008: A Study of 40 Cases from Delhi. Dengue Buletin; 35(12): 71-75.

Akintayo, E.T., Oshodi, A.A. and Esuoso, K.O. (1999). Effects of $\mathrm{NaCl}$, ionic strength and $\mathrm{pH}$ on the foaming and gelation of pigeon pea (Cajanins cajan) protein concentrates. Food Chemistry, 66: 51-56.

Amarteifio, J.O. and Moholo, D. (1998). The chemical composition of four legumes consumed in Botswana. Journal of Food Composition and Analysis, 11: 323333. 10.3923/pjn.2010.373.379.

Amarteifio, J.O., Tibe, O. and Njogu, R.M. (2006). The mineral composition of Bambara groundnut (Vigna subterranea (L) Verdc) grown in Southern Africa. African Journal of Biotechnology, 5: 2408-2411.

AOAC (2002). Method 932.12. Solids (soluble) in fruits and fruit products. Official Methods of Analyses of the Associate of Official Analytical Chemists (17 ed. Revision 1). AOAC, Washington D.C., USA.

AOAC, (2010) Official methods of analysis. $16^{\text {th }}$ edition. Virginia: AOAC International; 10.

Aremu, M.O, Olaofe, O. and Akintayo, E.T. (2007). Functional properties of some Nigerian varieties of legume seed flours and flour concentration effect on foaming and gelation properties. Journal of Food Technology, 5(2): 109-115.

Balogun, M. A., Arise, A. K., Kolawole, F. L., and Ijadinboyo, M. (2017). Effect of partial substitution of cow milk with Bambara Groundnut milk on the chemical composition, acceptability and shelf-life of yoghurt. Annals Food Science and Technology, 18(1): 96-99. 10.12691/ajfst-3-5-2.

Belewu, M.A., Fagbemi, T., Dosumu, O.O. and Adeniyi, M.O. (2008). Physicochemical and anti-nutritional properties of some lesser known tree and leguminous seeds. International Journal of Agricultural Research, 3(3): 237-242. 10.3923/ijar.2008.237.242.

Belewu, M. A., Belewu, K.Y. and Bamidele, R.A. (2010). Cyper-coconut yoghurt: preparation, compositional and organoleptic qualities. African Journal of Food Science and Technology, 1(1): 10-12.

Bohoua, G.L. and Yelakan, C.K. (2007). Effect of germinated sorghum flour on the performance of laying hens (Warren). International Journal of Poultry Science. 6(2): 122-124.

Brough, S., Azam-Ali, S. and Taylor, A. (1993). The potential of Bambara groundnut (Vigna subterranea) in vegetable milk production and basic protein functionality systems. Food Chemistry, 47(3): 277283. doi.org/10.1016/0308-8146(93)90161-8.

Chalas, B.J.M. (2013). Influence of "added" lactose on probiotic properties of yogurt culture bacteria and yogurt characteristics.(Doctoral dissertation, Louisana State University).

Charles, B., Mamudu, H.B., Joseph, U.I., Amin, O.I. (2015). Production and evaluation of yoghurt from mixtures of cow milk, milk extract from soybean and tiger nut. World Journal of Dairy and Food Sciences, 10(2): 159-169. 10.5829/idosi.wjdfs.2015.10.2.94216.

Ellah, M.M. and Singh, A. (2008). Bambara Groundnut (Vigna subterranea L. Verdc.) yield as influenced by phosphorus and cultivars in the semi-arid savanna of Nigeria. Journal of Plant Sciences 3(2): 176-181.

El-Niely, H.F.G (2007). Effect of Radiation Processing on Anti-nutrients, in-vitro protein Digestibility and Protein Efficiency ratio Bioassay of Legume seeds. Radiation Physics and Chemistry, 76: 1050-1057. 10.3923/ jps.2008.176.181.

Falade, K.O., Ogundele, O.M., Ogunshe, A.O., Fayemi, O.E. and Ocloo, F.C. (2014). Physicochemical, sensory and microbiological characteristics of plain yoghurt from bambara groundnut (Vigna subterranea) and soybeans (Glycine max). Journal of Food Science and Technology, 52(9): 5858-5865. 10.1007/s13197-0141657-3.

Farinde, E.O., Obatulu, V.A., Fasoyiro, S.B., Adeniran, A.H. and Agboola, E.R (2008). Use of alternative raw materials for yoghurt production. African Journal of Biotechnology, 7(18): 3339-3345.

Frank, A.A., Williams, O.E., Ibok, O. and Firibu, K.S. (2014). Effect of soaking and cooking methods on extraction of solids and acceptability of Tiger Nut (Cyperus esculentus L). milk. Journal of Agricultural studies, 2(2): 76-86. doi.org/10.5296/jas.v2i2.5991.

Igbabul, B., Shember, J. and Amove, J. (2014). Physicochemical, microbiological and sensory evaluation of yoghurt sold in Makurdi metropolis. African Journal of Food Science and Technology, 5(6): 129-135. dx.doi.org/10.14303/ajfst.2014.052.

Ijarotimi, S.O. and Esho, R. T. (2009). Comparison of nutritional composition and anti-nutrient status of fermented, germinated and roasted Bambara groundnut seeds (Vigna subterranea). British Food Journal, 111: 376-386. 10.1108/00070700910951515.

Izadi, Z., Nasirpour, A.,Garoosi, G.A. and Tamjidi, F. (2014). Rheological and physical properties of yogurt enriched with phytosterol during storage. Journal of Food Science and Technology, 52(8): 5341-5346. 10.1007/s13197-014-1593-2.

Jablonska, E., Gromadzinska, J., Klos, A., Bertrandt, J., Skibniewska, K., Darago, A. and Wasowicz W. (2013). Selenium, zinc and copper in the Polish diet. J. Food Comp. Anal. 31:259-265. 10.1016/j.jfca.2013.05.016

Jayaraman, J. (1981). Laboratory Manual in Biochemistry. Wiley Eastern Limited New Delhi. P-133

Khalifa, M., Elgasim, A., Zaghloul, A. and Maufouz, M. (2011). Application of inulin and mucilage as stabilizers in yoghurt production. American Journal of Food Technology, 1: 10-17. 10.3923/ajft.2011.31.39

Khan, Z.I., Ashraf, M., Hussain, A., McDowell, L.R., Ashraf, M.Y. (2008). Concentrations of minerals in milk of sheep and goats grazing similar pastures in semiarid region of Pakistan. Small Ruminant Research, 65: 274-278. 10.4236/ojas.2012.23019.

Kirk, R.S. and Sawyer, R. (1991). Pearson's Composition and Analysis of Foods. Longman Group LTD, UK. 9th ed. 188-189. 10.12691/ajfn-6-4-4

Lawal, O., Adebowale, K. and Adebowale, Y. (2007). 
Functional properties of native and chemically modified protein concentrates from Bambara groundnut. Food Research International, 40(8): 1003-1011. 10.1016/j. foodres.2007.05.011.

Majeste, M.P., Leopold, N.T., Clemence, B. and Nicolas Y.N. (2017). Production, nutritional and biological value of Bambara groundnut (Vigna subterranea) milk and yoghurt Journal of Food Measurement and Characterization. 1-11. 10.1007/s11694017-9541-2.

Massawe, F.J., Dickinson, M., Roberts, J.A. and Azam-Ali, S.N. (2002). Genetic diversity in Bambara groundnut landraces (Vigna subterranea (L.) Verdc) revealed by AFLP markers. Genome, 45: 1175-1180. 10.1139/g02093.

Mbaeyi, I.E. (2005). Production and evaluation of breakfast cereal using pigeon-pea (Cajanus cajan) and sorghum (Sorghum bicolor L.) An M.Sc. Thesis Department of Food Science and Technology, University of Nigeria, Nsukka. 10.1007/s13197-015-2032-8.

Muhammed, B.F., Alhassan, A.J. and Kabiru H.J. (2008). Quality evaluation of commercial yoghurts on streets of Kano - Nigeria. Resource Journal of Dairy Science, 2(4): 63-67.

Murevanhema, Y. Y. and Jideani, V. A. (2013). Potential of BGN (Vigna subterranea (L.) Verdc) Milk as a Probiotic Beverage-A Review. Critical Reviews in Food Science and Nutrition, 53: 954-967. doi.org/10.1080/10408398 .2011 .574803

Murevanhema, Y.Y. and Jideani, V.A. (2014). Production and Characterization of Milk Produced From BGN (Vigna subterranea ) Varieties. Journal of Food Processing and Preservation, 39(6): 1-14. 10.1111/ jfpp. 12368

Ndidi, U.S., Ndidi, C.U., Olagunju, A., Muhammad, A., Billy F.G., and Okpe, O. (2014). Proximate, antinutrients and mineral composition of raw and processed (boiled and roasted) Sphenostylis stenocarpa seeds from Southern Kaduna, Northwest, Nigeria, ISRN Nutrition, 14: 1-9. dx.doi.org/10.1155/2014/280837.

Nnam., N.M. (1997). Chemical and sensory evaluation of vegetable milks from African yam bean Sphenostylis stenocarpa (Hochst ex A Rich) Harms and maize (Zea mays L.). Plant Foods for Human Nutrition, 51: 265275. doi.org/10.1023/A:1007918011504.

Obizoba, I.C. and Egbuna, H.I. (1992). Effect of germination and fermentation on the nutritional quality of Bambara nut (Voandzeia subterranea L. Thouars) and its product (milk). Plant Foods for Human Nutrition, 42: 13-23. 10.3923/pjn.2009.1849.1854.

Ojinnaka, M.C., Ebinyasi, C.S., Ihemeje, A. and Okorie, S.U. (2013). Nutritional evaluation of complementary food gruels formulated from blends of soybean flour and ginger modified cocoyam starch. Advance Journal of Food Science and Technology, 5(10):1325-1330. 10.19026/ajfst.5.3105.

Okafor, J.N.C., Ani, J.C. and Okafor, G.I. (2014). Effect of processing methods on qualities of Bambara groundnut (Voandzeia subterranea (L.) Thouars) flour and their acceptability in extruded snacks. American Journal of Food Technology, 9(7): 350-359. 10.3923/ ajfst.2014.350.359.
Omoikhoje, S.O. (2008). Assessment of the nutritive value of Bambara groundnut as influenced by cooking time. Livestock Research for Rural Development. 20(4): 1-15. Onwuka, G.I. (2005). Food Analysis and Instrumentation: Theory and Practice ( $1^{\text {st }}$ ed.), Naphtali Publishers, Lagos, Nigeria. 10.12691/jfnr-2-4-8.

Oyeleke, G.O., Afolabi, O. and Isola, A.D. (2012). Some quality characteristics and carbohydrate fractions of Bambara groundnut (Vigna subterranea L.) seed flour. IOSR Journal of Applied Chemistry, 2(4): 16 -19. 10.9790/5736-0241619.

Potter, N.N. and Hotchkiss, J.H. (1996). Food Science, CBS Publishers and Distributors Pvt. Ltd. New Delhi. pp. 279-314.

Poulter, N.H., (1981): Properties of some protein fractions from Bambara groundnut (Voandezeia subterranean). Thoura. Journal of the Science of Food and Agriculture, 32(1): 44-50. doi.org/10.1002/ jsfa.2740320108.

Quasem, J.M., Mazahreh A.S. and Abu-Alruz, K. (2009). Development of vegetable based milk from decorticated sesame (Sesamum Indicum). American Journal of Applied Sciences, 6: 888-896. doi.org/10.3844/ ajassp.2009.888.896.

Reh, C.T. and Gerber, A. (2003). Total solids determination in dairy products by microwave oven technique. Food Chemistry, 82(1): 125-131. 10.1016/s03088146(02)00585-X

Sathe, S.K. and Salunkhe, D.K. (1981). Functional properties of the great northern bean (Phaseolus vulgaris L.) proteins, emulsion, foaming, viscosity and gelation properties. Journal of Food Science, 46: 7176. doi.org/10.1111/j.1365-2621.1981.tb14533.

Sunny - Roberts, E.O., Otunola, E.T. and Iwakun B.T. (2004). An evaluation of some quality parameters of a laboratory prepared fermented groundnut milk. Euro. Food Res. Technol, 218: 452-455. doi. org/10.1111/j.1365-2621.1981.tb14533.x.

Venter, C.S. and Van Eyssen, E. (2001). More legumes for better overall health. South African Journal of Clinical Nutrition, 32-38.

Wheeler, E.L. and Ferrel, R.E. (1971). A method of phytic acid determination in wheat. Cereal Chemistry, 48: 312-316.

Yusuf, A.A, Mofio, B.M., and Ahmed, A.B. (2007). Proximate and mineral composition of Tamarindus indica Linn 1753 seeds. Science World Journal 2:1-4. 10.4314/swj.v2i1.51699.

Yusuf, A.O. (2017): Quality and Storage Stability of Yoghurt Produced from Pigeon Pea Milk Supplemented with Propionibacterium freudenreichii. Thesis submitted in fulfilment of the academic requirements for the degree of master of applied science in food science and technology In the Department of Biotechnology and Food Technology Faculty of Applied Sciences Durban University of Technology South Africa. 1-96. 